\title{
Analisis Pengetahuan Matematika, Didaktika, dan Teknologi Calon Guru Sekolah Dasar Menggunakan Rasch Model
}

\author{
Zetra Hainul Putra ${ }^{*}$, Neni Hermita², Jesi Alexander Alim³ \\ Fakultas Keguruan dan Ilmu Pendidikan, Universitas Riau \\ Jl. HR Soebrantas Km 12.5, Pekanbaru, Riau, Indonesia \\ ${ }^{1 *}$ zetra.hainul.putra@lecturer.unri.ac.id; ${ }^{2}$ neni.hermita@lecturer.unri.ac.id; \\ 3jesi.alexander@lecturer.unri.ac.id
}

Artikel diterima: 12-04-2021, direvisi: 17-09-2021, diterbitkan: 30-09-2021

\begin{abstract}
Abstrak
Pengetahuan matematika, didaktika, dan teknologi yang harus dimilik oleh calon guru dan guru, sebelumnya diukur dengan metode classical test theory (CTT), namun memiliki keterbatasan. Penelitian bertujuan mengetahui pengetahuan tersebut dengan metode yang diprekdiksi lebih akurat yaitu item response theory (IRT) dari rasch model. Metode penelitian meliputi survey pengetahuan matematika dan didaktika serta survey pengetahuan teknologi menggunakan angket. Subjek penelitian yaitu 38 mahasiswa tahun kedua calon guru sekolah dasar dari sebuah institusi pendidikan guru sekolah dasar di Pekanbaru. Hasil studi menunjukkan calon guru sekolah dasar memiliki pengetahuan matematika dan teknologi cukup baik, namun pengetahuan didaktika sangat rendah. Analisis pengetahuan calon guru menggunkan rasch model mampu memberikan gambaran tingkat kesulitan soal/item yang diberikan, tingkat pengetahuan responden, dan interaksi antar responden dan antar soal. Institusi pendidikan perlu mengembangkan pembelajaran bagi calon guru sekolah dasar yang mampu mendukung penguatan dan pengembangan pengetahuan matematika, didaktika, dan teknologi.

Kata Kunci: pengetahuan didaktika, pengetahuan matematika, pengetahuan teknologi; rasch model.
\end{abstract}

\section{Prospective Elementary Teachers' Mathematical, Didactic, and Technological Knowledge Using Rasch Model Analysis}

\begin{abstract}
Knowledge of mathematics, didactics, and technology that must be owned by pre-service and in-service teachers, previously measured by the classical test theory (CTT), but has limitations. Study aims to determine that knowledge with a more accurate prediction method using the item response theory (IRT) from the Rasch model. Study used a survey of mathematical and didactic knowledge, and a survey of technological knowledge with a scale. The subjects were 38 secondyear students from an elementary school teacher education institution in Pekanbaru. This study indicates that pre-service teachers have relatively sufficient mathematics and technological knowledge, but they were lack of didactic knowledge. Analysis of pre-service teachers' knowledge using the Rasch model can provide an overview of the difficulty level of the items given, the level of pre-service teachers' knowledge, and the interaction between respondents and between questions. Institutions need to develop learning instruction for pre-service teachers that can support the strengthening and development of their mathematical, didactic, and technological knowledge.

Keywords: didactical knowledge, mathematical knowledge, technological knowledge, rasch model.
\end{abstract}




\section{Pendahuluan}

Perkembangan dan kemajuan teknologi menuntut guru memiliki kemampuan matematika, didaktika dan teknologi yang memadai dalam mengajar siswa-siswa sekolah dasar. Pengetahuan matematika guru yang kurang memadai akan berdampak terhadap pengetahuan didaktika mereka yaitu pengetahuan terkait dengan kemampuan mengajarkan pengetahuan matematika ke siswa, termasuk siswa sekolah dasar (Putra, 2019a, 2019b; Putra et al., 2020). Sementara itu, dengan kemajuan teknologi dan pandemi Covid-19 yang mewabah saat ini, mereka juga dituntut memiliki pengetahuan teknologi yang mumpuni dan memiliki sikap positif dalam penggunaan teknologi digital dalam pembelajaran (Pamuk \& Peker, 2009).

Beragam penelitian tentang pengetahuan calon guru dan guru telah dilakukan, baik fokus pada pengetahuan matematika dan didaktika saja (Depaepe et al., 2015; Newton, 2008; Putra, 2018, 2019b), maupun melibatkan pengetahuan teknologi calon guru dan guru sekolah dasar (Hu et al., 2013; Kildan \& Incikabi, 2015; Liu et al., 2015; Restiana \& Pujiastuti, 2019). Sebagian besar studi tersebut menunjukkan bahwa calon guru maupun guru mengalami kesulitan dalam memahami beberapa konsep matematika dan juga menjelaskan kepada siswa sekolah dasar. Kesulitan mengajar tidak hanya dirasakan oleh guru sekolah dasar tetapi juga guru di sekolah menengah pertama bahkan di perguruan tinggi. Sementara itu, penelitian yang dilakukan oleh Mailizar, Almanthari, Maulina, dan Bruce (2020) menunjukkan bahwa guru matematika di sekolah atas memiliki tantangan terbesar dalam menggunakan e-learning dalam pembelajaran di masa pandemi Covid-19.

Penelitian sebelumnya umumnya mengukur pengetahuan calon guru dan guru menggunakan classical test theory (CTT) dimana teori tersebut memiliki keterbatasan pengukuran (Sumintono \& Widhiarso, 2013). Sebagai contoh keterbatasan dari CTT yaitu dibutuhkan banyak butir untuk mendapatkan pengukuran yang berkualitas (Sumintono \& Widhiarso, 2013).

Mengingat pentingnya informasi tentang pengetahuan matematika, didaktika, dan teknologi calon guru dan guru yang akurat dan tepat, maka item response theory (IRT) dari rasch model merupakan sebuah model yang diprediksi tepat untuk digunakan dalam pengukuran tersebut. Hal ini karena pada pengukuran menggunakan rasch model mampu menjelaskan interaksi antara orang dengan butir soal/item (Sumintono \& Widhiarso, 2013). IRT lebih baik dalam pengukuran karena mampu memberikan estimasi yang lebih tepat untuk pengukuran. Oleh karena itu, dalam studi ini peneliti tertarik untuk mengetahui pengetahuan matematika, didaktika, dan teknologi calon guru sekolah dasar menggunakan analisis rasch model. Penelitian ini diharapkan berkontribusi terhadap pemberian informasi terkait 
dengan pengetahuan matematika, didaktika, dan teknologi calon guru sekolah dasar yang lebih akurat dan juga memberikan pengetahuan kepada pembaca tentang penggunaan rasch model dalam mengukur pengetahuan calon guru tersebut.

\section{Metode}

Penelitian ini menggunakan metode survey dalam pengumpulan data berbasis teknologi (Cohan et al., 2007). Dalam pelaksanaannya, peneliti menyiapkan instrumen tes pengukuran pengetahuan matematika dan didaktika calon guru sekolah dasar, sedangkan untuk pengukuran pengetahuan teknologi yaitu menggunakan angket. Subjek dalam penelitian ini berjumlah 38 orang mahasiswa semester 4 pendidikan guru sekolah dasar dari sebuah institusi pendidikan di provinsi Riau, Indonesia. Subjek diberi kode S1 hingga S38 untuk mempermudah dalam menganalisis data. Subjek merupakan mahasiswa yang sedang mengambil mata kuliah pendidikan matematika SD kelas tinggi, dan mereka setidaknya telah menyelesaikan 3 mata kuliah terkait matematika dan pendidikan matematika yaitu bilangan dan aljabar, geometri dan pengukuran, serta pendidikan matematika SD kelas rendah. Sementara itu, sejak adanya Covid-19, perkuliahan dilaksanakan secara daring sehingga mereka sudah tidak asing lagi dengan teknologi digital dalam pembelajaran.
Pengukuran pengetahuan matematika calon guru memuat 5 pertanyaan terbuka yang meliputi pengukuran keliling bangun datar, luas bangun datar, pengukuran sudut, serta representasi pecahan dan statistika. Gambar 1 menyajikan contoh soal pengukuran pengetahuan matematika calon guru sekolah dasar tentang keliling gabungan 2 buah bangun datar. Soal matematika yang diberikan tidak hanya meminta responden untuk menuliskan jawaban akhirnya saja tetapi juga cara menemukan jawabannya.

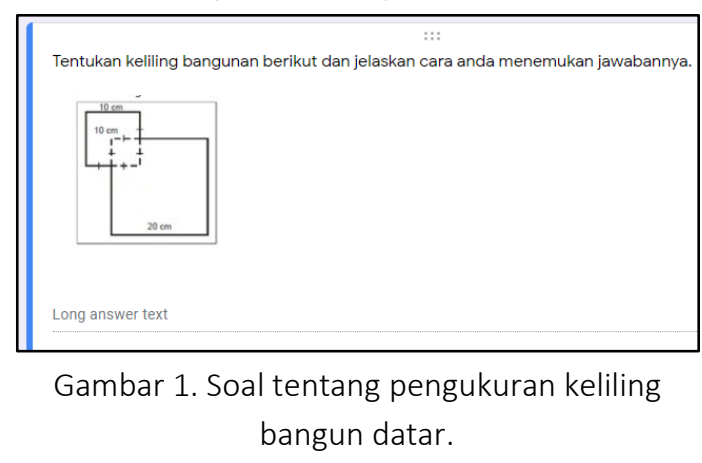

Pengukuran pengetahuan didaktika calon guru sekolah dasar juga memuat 5 pertanyaan. Empat pertanyaan memberikan situasi kepada responden untuk mengevaluasinya dan kemudian memberikan pandangan apakah mereka setuju dengan situasi tersebut atau tidak. Selanjutnya mereka diminta untuk menjelaskan alasannya. Sementara itu 1 pertanyaan meminta responden untuk merancang sebuah soal kontekstual tentang pembagian pecahan dan memberikan beberapa cara untuk mengajarkannya. Gambar 2 menyajikan sebuah ilustrasi soal didaktik tentang 
perbandingan pecahan. Soal ini diadaptasi dari penelitian Putra (2018).

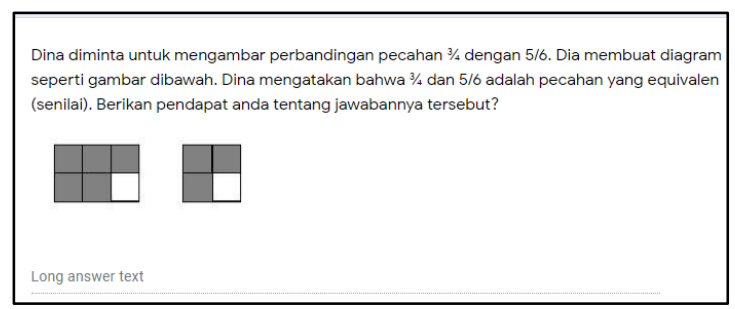

Gambar 2. Soal didaktik tentang pecahan senilai.

Sementara itu, pengetahuan teknologi calon guru sekolah dasar diukur melalui angket berjumlah 11 peryataan dengan menggunakan skala likert (1-5). Instrumen disusun berdasarkan riset yang dilakukan oleh Mailizar dkk., (2020) dan Fogarty dkk., (2001) yaitu terkait dengan pengetahuan tentang pengunaan ICT dalam belajar matematika (Item 1, 3, 4, dan 6) penggunaan ICT dalam berkolaborasi (item 2, 5, dan 7, dan 11), dan pengetahuan tentang ICT untuk pembelajaran matematika yaitu Geogebra (item 8, 9, dan 10).

Tabel 1.

Instrumen pengukuran pengetahuan teknologi

\begin{tabular}{|ll|}
\hline No & \multicolumn{1}{c}{ Peryataan } \\
\hline 1 & $\begin{array}{l}\text { Saya bisa belajar matematika lebih baik } \\
\text { dengan bantuan teknologi. }\end{array}$ \\
& $\begin{array}{l}\text { Pada masa pandemic ini, saya kesulitan } \\
\text { untuk berdiskusi dengan teman mengenai } \\
\text { tugas yang diberikan karena harus } \\
\text { menggunakan teknologi. }\end{array}$ \\
\hline 3 & $\begin{array}{l}\text { Saya masih gagap teknologi terutama } \\
\text { terkait perkuliahan matematika }\end{array}$ \\
\hline 4 & $\begin{array}{l}\text { Selama pandemi, pemahaman dan } \\
\text { pengalaman belajar matematika saya } \\
\text { meningkat karena menggunakan } \\
\text { teknologi. }\end{array}$ \\
\hline 5 & $\begin{array}{l}\text { Saya merasa lebih mudah berkolaborasi } \\
\text { dengan teman dalam menyelesaikan }\end{array}$ \\
\hline
\end{tabular}

\begin{tabular}{|l|l|}
\multicolumn{1}{|c|}{$\begin{array}{l}\text { tugas matematika melalui penggunaan } \\
\text { teknologi. }\end{array}$} \\
\hline 6 & $\begin{array}{l}\text { Saya menyelesaikan tugas matematika } \\
\text { lebih cepat karena menggunakan } \\
\text { teknologi. }\end{array}$ \\
\hline 7 & $\begin{array}{l}\text { Dalam menyelesaikan tugas matematika, } \\
\text { lebih mudah mengkomunikasikannya } \\
\text { secara tatap muka langsung dari pada } \\
\text { menggunakan teknologi }\end{array}$ \\
\hline 8 & $\begin{array}{l}\text { Saya mengenal Geogebra sebagai } \\
\text { software matematika }\end{array}$ \\
\hline 9 & $\begin{array}{l}\text { Saya menggunakan Geogebra untuk } \\
\text { meningkatkan pemahaman tentang } \\
\text { matematika }\end{array}$ \\
\hline 10 & $\begin{array}{l}\text { Saya dapat merancang pembelajaran } \\
\text { matematika menggunakan Geogebra }\end{array}$ \\
\hline 11 & $\begin{array}{l}\text { Diskusi secara daring menggunakan } \\
\text { zoom, googlemeet, atau program tatap } \\
\text { maya lainnya membantu saya memahami } \\
\text { materi perkuliahan matematika lebih baik }\end{array}$ \\
\hline
\end{tabular}

Pengumpulan data dilakukan pada bulan Maret 2021 dan dilakukan secara daring menggunakan Google Forms yang terintegrasi dengan Google Classroom peneliti pertama. Waktu yang diberikan kepada responden untuk menyelesaikan survey yaitu 75 menit. Soal matematika dan didaktika diberikan secara bersamaan dan acak, kemudian dilanjutkan dengan pengisian angket pengukuran pengetahuan teknologi.

Hasil jawaban mahasiswa terhadap pertanyaan matematika dan didaktika diberi skor 0, 1, dan 2. Skor 0 diberikan kepada responden yang memberi jawaban salah, skor 1 untuk responden dengan jawaban benar tanpa penjelasan ataupun dengan penjelasan yang keliru, dan skor 2 untuk responden yang memberi jawaban benar dan alasan yang benar juga. 
Teknik analisis data dalam penelitian ini menggunakan rasch model (Sumintono \& Widhiarso, 2013). Sebagaimana dijelaskan di pendahuluan, rasch model dipilih karena memberikan hasil pengukuran yang lebih tepat dan akurat. Analisis data menggunakan program Ministep yang dapat diunduh di www.winsteps.com. Analisis data meliputi evaluasi daya diskriminasi, Tingkat kesulitan butir instrument, peta butir dan individu, serta fungsi informasi pengukuran sehingga dapat diketahui sejauh mana pengetahuan matematika, didaktika, dan teknologi calon guru sekolah dasar.

\section{Hasil dan Pembahasan}

\section{A. Hasil Penelitian}

Hasil penelitian ini disajikan dalam 3 subbab yaitu tentang analisis pengetahuan matematika, pengetahuan didaktika, dan pengetahuan teknologi calon guru sekolah dasar.

\section{Pengetahuan Matematika Calon Guru Sekolah Dasar}

Analisis pertama yang dilakukan yaitu melihat informasi secara keseluruhan tentang kualitas responden dan kualitas instrument yang digunakan serta interaksi antara responden. Dari analisis data menggunakan rasch model diperoleh ratarata kemampuan subyek dalam menjawab soal yaitu 0,1 logit. Artinya peserta cenderung memberi jawaban terhadap soal yang diberikan diatas nilai tengah. Nilai person reliability yaitu 0,44 sedangkan item reliability yaitu 0,94 . Hal ini berarti konsistensi jawaban dari responden lemah tetapi kualitas item instrument sangat bagus dalam mengukur kemampuan matematika calon guru sekolah dasar. Selanjutnya nilai separation responden 0.88 sedangkan nilai separation item 3,93. Hal ini menunjukkan pengelompokan item sangat bagus daripada pengelompokan responden.

Tabel 2 menyajikan informasi tentang kualitas item soal yang diberikan kepada calon guru sekolah dasar. Soal tentang representasi penjumlahan pecahan memperoleh nilai pengukuran tertinggi yaitu 2,57. Hal ini menunjukkan bahwa soal ini merupakan soal yang paling sulit dikerjakan oleh responden, sedangkan soal statistika memperoleh nilai terendah yaitu -1,02 yang berarti soal yang paling mudah diselesaikan oleh responden. Sementara itu, dari ke-5 soal, terdapat 1 soal yang misfit atau kurang sesuai dalam mengukur pengetahuan matematika calon guru sekolah dasar yaitu soal tentang representasi penjumlahan pecahan karena nilainya berada di luar standar yang ditetapkan yaitu antara 0,5 dan 1,5. Walaupun demikian, soal tentang representasi penjumlahan dan pengurangan pecahan tidak dikeluarkan karena satu-satunya soal yang mengukur pengetahuan pecahan calon guru sekolah dasar. 
Tabel 2.

Pengukuran soal dan fit statistics untuk pengetahuan matematika

\begin{tabular}{|cccccc|}
\hline No & Soal & $\begin{array}{c}\text { Pengu } \\
\text { kuran }\end{array}$ & Infit & Outfit & $\begin{array}{c}\text { PT- } \\
\text { Pengu } \\
\text { kuran }\end{array}$ \\
\hline 1 & $\begin{array}{c}\text { Representasi } \\
\text { penjumlahan } \\
\text { pecahan }\end{array}$ & 2,57 & 1.25 & 5.57 & 0.27 \\
\hline & & & & \\
\hline 2 & $\begin{array}{c}\text { Pengukuran } \\
\text { sudut }\end{array}$ & $-0,28$ & 0,72 & 0,62 & 0,69 \\
\hline 3 & $\begin{array}{c}\text { Luas bangun } \\
\text { datar }\end{array}$ & $-0,53$ & 0,73 & 0,52 & 0,68 \\
\hline 4 & $\begin{array}{c}\text { Keliling bangun } \\
\text { datar }\end{array}$ & $-0,74$ & 1,30 & 1,03 &,- 47 \\
\hline 5 & \begin{tabular}{c} 
Statistika \\
\multicolumn{7}{c|}{}
\end{tabular} & $-1,02$ & 1,03 & 0,79 & 0,51 \\
\hline
\end{tabular}

Gambar 3 menampilkan peta soal/responden untuk pengukuran pengetahuan matematika calon guru sekolah dasar. Dari gambar 3 terlihat soal representasi penjumlahan pecahan merupakan soal yang paling sulit dikerjakan oleh responden. Tingkat kesulitannya berada pada skor 2,57. Walaupun demikian, Responden 375 mampu menyelesaikan soal tersebut. Responden 375 merupakan responden yang memiliki kemampuan sangat tinggi. Responden tersebut tidak mengalami kesulitan dalam menyelesaikan soal-soal yang diberikan. Sementara itu soal 4 tentang statistika merupakan soal yang paling mudah namun masih terdapat 6 orang responden yang tidak mampu mengerjakannya.

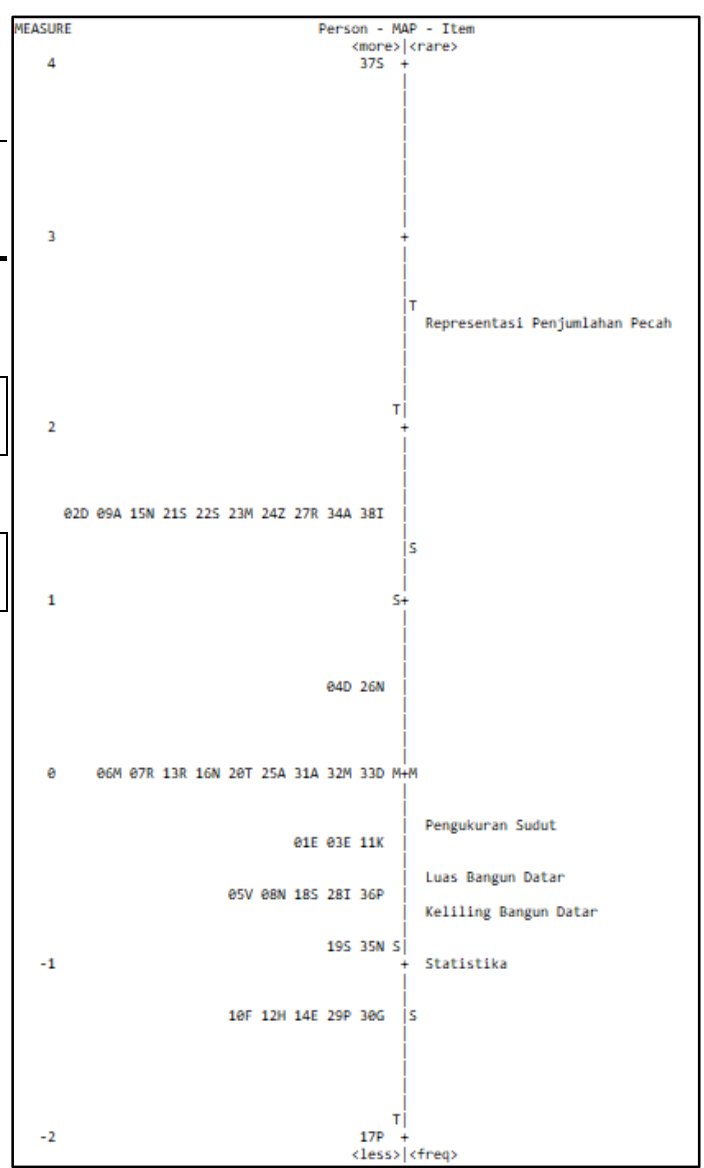

Gambar 3. Peta sebaran Pengetahuan Matematika dan tingkat kesulitan soal.

\section{Pengetahuan Didaktika Calon Guru Sekolah Dasar}

Data hasil analisis Rasch diperoleh ratarata kemampuan responden dalam menjawab soal yaitu -1,17 logit. Artinya responden memiliki kemampuan dibawah rata-rata dalam menjawab soal yang diberikan. Nilai person reliability yaitu 0,55 sedangkan item reliability yaitu 0,94. Hal ini berarti konsistensi jawaban dari responden lemah tetapi kualitas item dalam instrumen sangat bagus dalam mengukur kemampuan didaktika calon guru sekolah dasar. Selanjutnya nilai separation responden 1,10 sedangkan nilai separation 
item 4,09. Hal ini menunjukkan bahwa pengelompokan item sangat bagus daripada pengelompokan responden.

Tabel 3 menyajikan informasi tentang kualitas item soal yang diberikan kepada calon guru sekolah dasar. Soal tentang rasio memperoleh nilai pengukuran tertinggi yaitu 1,12 . Hal ini menunjukkan bahwa soal ini merupakan soal yang paling sulit dikerjakan oleh calon guru sekolah dasar, sedangkan soal pecahan senilai memperoleh nilai terendah yaitu $-2,59$ yang berarti soal yang paling mudah diselesaikan oleh calon guru sekolah dasar. Sementara itu, dari tabel 3 terlihat bahwa soal tentang pembagian pecahan dengan pecahan memiliki nilai Outfit lebih besar dari 1,5 tetapi PT-Pengukuran terletak diatara 0,4 dan 0,85, sedangkan soal pecahan senilai nilai PT-Pengukurannya berada diluar rentang yang ditetapkan namun nilai oufitnya dibawah 1,5 . Karena salah satu dari kriteria oufit masih memenuhi, maka kedua soal tersebut masih tetap dipertahankan.

Tabel 3.

Pengukuran soal dan fit statistics untuk pengetahuan didaktika

\begin{tabular}{|c|c|c|c|c|c|}
\hline No & Soal & $\begin{array}{c}\text { Peng } \\
\text { ukura } \\
n\end{array}$ & $\begin{array}{c}\text { Inf } \\
\text { it }\end{array}$ & $\begin{array}{l}\text { Out } \\
\text { fit }\end{array}$ & $\begin{array}{c}\text { PT- } \\
\text { Penguk } \\
\text { uran }\end{array}$ \\
\hline 1 & $\begin{array}{c}\text { Perbandi } \\
\text { ngan } \\
\text { Pecahan }\end{array}$ & 0,39 & $\begin{array}{l}0 \\
94\end{array}$ & $\begin{array}{c}2,5 \\
7\end{array}$ & 0,45 \\
\hline 2 & $\begin{array}{c}\text { Pembagi } \\
\text { an } \\
\text { Pecahan } \\
\text { dengan } \\
\text { Pecahan }\end{array}$ & 0,17 & $\begin{array}{l}1 \\
17\end{array}$ & $\begin{array}{c}1,7 \\
7\end{array}$ & 0,52 \\
\hline 3 & Peluang & 0,19 & $\begin{array}{l}0, \\
96\end{array}$ & $\begin{array}{c}0,5 \\
8\end{array}$ & 0,56 \\
\hline
\end{tabular}

\begin{tabular}{|cccccc|}
\hline 4 & Rasio & 1,12 & 0, & 0,5 & 0,51 \\
& & & 94 & 8 & \\
\hline 5 & Pecahan & $-2,59$ & 0, & 0,3 & 0,87 \\
& Senilai & & 65 & 0 & \\
\hline
\end{tabular}

Gambar 4 menampilkan peta soal/ responden untuk pengukuran pengetahuan didaktika calon guru sekolah dasar. Dari gambar 4 terlihat bahwa soal pecahan senilai merupakan soal yang sangat mudah dikerjakan oleh responden. Tingkat kesulitannya berada pada skor 2,59 . Sedangkan 4 soal lagi berada pada kelompok yang sama yaitu pada rentang 0 hingga 1 logit. Sementara itu kemampuan didaktika responden sangat bervariasi, namun banyak responden yang memiliki kemampuan didaktika sangat rendah dan rendah. Sementara itu terdapat 1 responden, yaitu S24 yang memiliki kemampuan didaktika yang sangat tinggi dan kemudian disusul oleh 33D yang tingkat kemampuannya juga tinggi dan dapat menyelesaikan soal tentang rasio namun tidak optimal. 


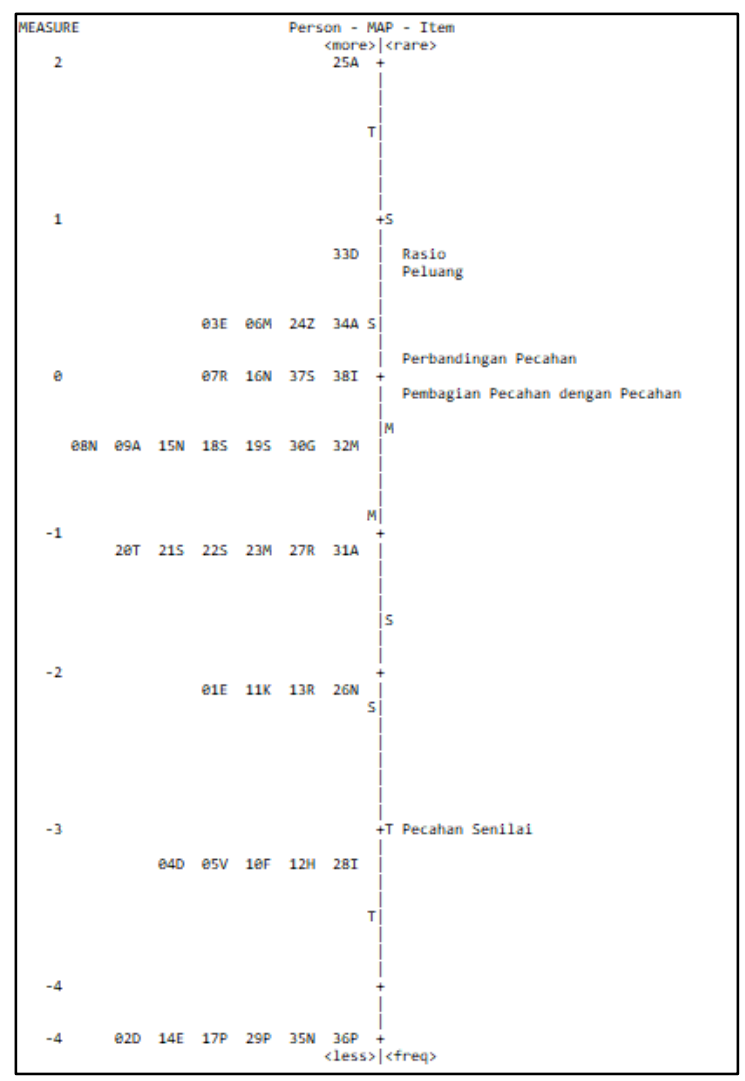

Gambar 4. Peta sebaran Pengetahuan Didaktika dan tingkat kesulitan soal.

\section{Pengetahuan Teknologi Calon Guru Sekolah Dasar}

Analisis yang dilakukan pertama yaitu melihat informasi secara keseluruhan tentang kualitas responden dan kualitas instrument yang digunakan serta interaksi antara subyek. Data yang diperoleh yaitu rata-rata kemampuan subyek dalam menjawab soal yaitu -0,29 logit. Artinya peserta cenderung memberi jawaban terhadap soal yang diberikan dibawah nilai tengah. Nilai person reliability yaitu 0,72 sedangkan item reliability yaitu 0,94. Hal ini berarti konsistensi jawaban dari responden bagus dan kualitas item dalam instrumen sangat bagus dalam mengukur kemampuan teknologi calon guru sekolah dasar. Selanjutnya nilai separation responden 1.59 sedangkan nilai separation item 3,82. Hal ini menunjukkan bahwa pengelompokan item sangat bagus daripada pengelompokan responden.

Tabel 4 menyajikan informasi tentang kualitas item angket yang diberikan kepada calon guru sekolah dasar. Angket Q7 (Dalam menyelesaikan tugas matematika, lebih mudah mengkomunikasikannya secara tatap muka langsung dari pada menggunakan teknologi) memperoleh nilai pengukuran tertinggi yaitu 2,18 . Hal ini menunjukkan bahwa peryataan ini merupakan peryataan yang paling sulit disetujui oleh calon guru sekolah dasar, sedangkan angket Q1 (Saya bisa belajar matematika lebih baik dengan bantuan teknologi) memperoleh nilai terendah yaitu -0,99 yang berarti peryataan yang paling mudah disetujui oleh calon guru sekolah dasar. Sementara itu, semua peryataan yang diujikan memenuhi kriteria oufit yang ada jadi layak digunakan untuk mengukur pengetahuan teknologi calon guru sekolah dasar.

Tabel 4.

Pengukuran soal dan fit statistics untuk pengetahuan teknologi

\begin{tabular}{cccccc|}
\hline No & Item & $\begin{array}{c}\text { Peng } \\
\text { ukura } \\
\mathrm{n}\end{array}$ & Infit & Outfit & $\begin{array}{c}\text { PT- } \\
\text { Penguk } \\
\text { uran }\end{array}$ \\
\hline 1 & Q7 & 2,18 & 1,39 & 2,30 & 0,11 \\
\hline 2 & Q2 & 0,86 & 1,29 & 1,27 & 0,47 \\
\hline 3 & Q3 & $-0,16$ & 1,18 & 1,19 & 0,26 \\
\hline 4 & Q1 & $-0,93$ & 1,15 & 1,09 & 0,61 \\
\hline 5 & Q5 & $-0,44$ & 1,03 & 1,03 & 0,55 \\
\hline 6 & Q6 & $-0,44$ & 0,90 & 1,01 & 0,52 \\
\hline 7 & Q11 & $-0,32$ & 0,98 & 1,01 & 0,43 \\
\hline
\end{tabular}




\begin{tabular}{|cccccc|}
\hline 8 & Q9 & $-0,28$ & 0,90 & 0,88 & 0,62 \\
\hline 9 & Q10 & $-0,03$ & 0,90 & 0,87 & 0,51 \\
\hline 10 & Q8 & $-0,44$ & 0,81 & 0,80 & 0,72 \\
\hline 11 & Q4 & $-0,06$ & 0,62 & 0,62 & 0,74 \\
\hline
\end{tabular}

Gambar 5 menampilkan peta peryataan/responden untuk pengukuran pengetahuan teknologi calon guru sekolah dasar. Dari gambar 5 terlihat bahwa terdapat 4 kelompok peryataan, yaitu peryataan yang sangat sulit disetuji (Q7), peryataan yang sulit disetujui (Q2), peryataan yang paling mudah disetujui (Q1) dan sisanya adalah peryataan yang berada di sekitar nilai pemusatan data. Sementara itu, dari kelompok responden, terdapat 3 responden yang memiliki pengetahuan teknologi yang tinggi (24Z, 23M, 03E), namun sangat sulit setuju dengan peryataan Q7. Sementara itu 22S, 18S, 28I, $32 \mathrm{M}$ merupakan responden yang memberikan persetujuan yang paling rendah, bahkan dengan peryataan Q1 yang pada umumnya disetujui oleh banyak orang, merekapun sulit untuk menyetujuinya. Dalam hal ini mereka belum bisa memperoleh manfaat yang besar dari teknologi dalam pembelajaran matematika.

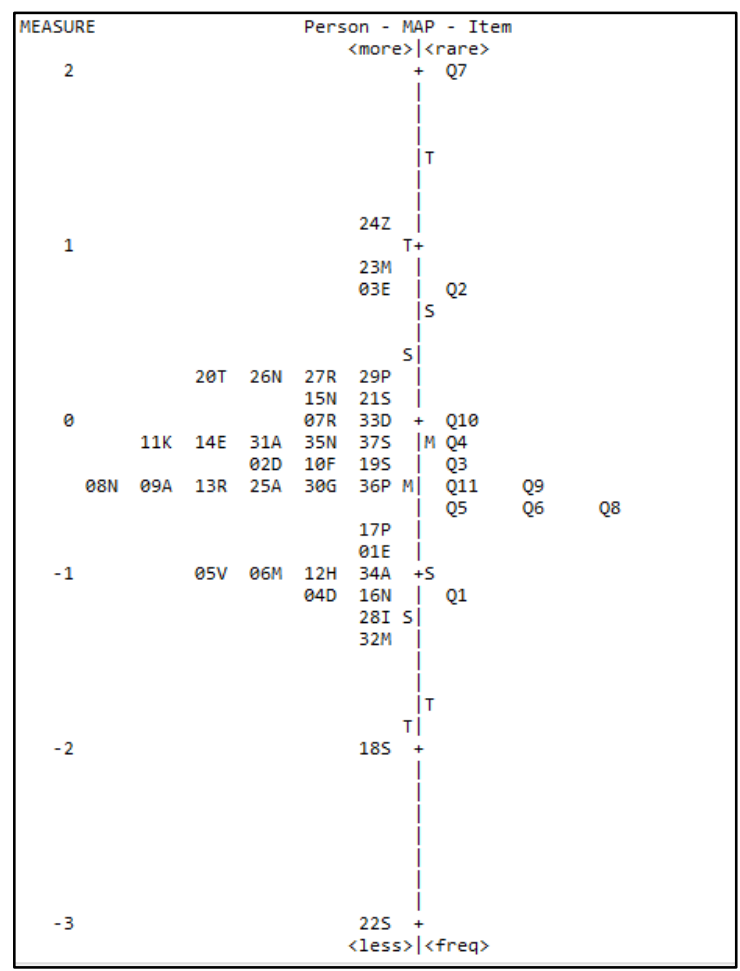

Gambar 5. Peta sebaran Pengetahuan teknologi dan tingkat kesulitan instrument.

\section{B. Pembahasan}

Penelitian ini bertujuan untuk menganalisis pengetahuan matematika, didaktika, dan teknologi calon guru sekolah dasar menggunakan analisis rasch model. Dari hasil studi ini, diperoleh data bahwa calon guru sekolah dasar memiliki pengetahuan matematika dan teknologi yang cukup, namun pengetahuan didaktika yang rendah.

Pengetahuan matematika calon guru sekolah dasar yang masih pada kategori cukup sejalan dengan hasil studi-studi sebelumnya (Depaepe dkk., 2015; Putra, 2019b; van Steenbrugge dkk., 2014), namun, penelitian sebelumnya umumnya memfokuskan pada pengetahuan pecahan 
calon guru sekolah dasar. van Steenbrugge dkk. (2014), misalnya, menemukan bahwa calon guru sekolah dasar memiliki pengetahuan yang terbatas tentang pecahan dan mahasiswa tahun terakhir memiliki pengetahuan pecahan yang tidak jauh lebih baik dari tahun pertama. Sementara itu, dari pengukuran tingkat kesulitan soal (gambar 3), pecahan memang merupakan soal yang paling sulit diselesaikan oleh calon guru sekolah dasar. Dengan mengukur pengetahuan mahasiswa tentang pecahan mungkin kita dapat memprediksi pengetahuan matematika mereka secara umum.

Calon guru sekolah dasar dalam studi ini memiliki pengetahuan didaktika sangat rendah. Hasil temuan ini didukung oleh studi-studi sebelumnya (Depaepe et al., 2015; Putra, 2019b; Putra et al., 2020), namun studi-studi tersebut juga memfokuskan pada pengukuran pengetahuan didaktik calon guru pada materi pecahan. Rendahnya pengetahuan didaktika calon guru tentu berdampak pada kemampuan mereka mengajar matematika kepada siswa nantinya di sekolah dasar. Hal ini karena pengetahuan didaktika guru mempengaruhi keberhasilan siswa dalam belajar matematika (Cueto et al., 2017). Dengan demikian, institusi pendidikan harus memberikan instruksional pembelajaran yang mampu mendukung penguatan pengetahuan didaktika calon guru, baik calon guru sekolah dasar maupun calon guru matematika.
Sementara itu, calon guru sekolah dasar dalam studi ini juga memiliki pengetahuan teknologi pada tingkatan cukup. Temuan penelitian ini didukung oleh penelitian Putra et al., (2020) bahwa calon guru sekolah dasar memiliki perspektif bahwa perkuliahan secara daring kurang efekti dalam mendukung mereka memahami konsep matematika, interaksi dengan dosen dan mahasiswa lain, serta dalam mengerjakan tugas yang diberikan. Namun, kendala tersebut lebih disebabkan oleh jaringan internet yang buruk dan ketidak tersedian data internet. Namun demikian, pemanfaatan teknologi digital dimasa pandemi Covid-19 ini menjadi pilihan yang paling masuk akal untuk dilaksanakan dalam pembelajaran baik di sekolah maupun di perguruan tinggi.

\section{Penutup}

Pengetahuan matematika, didaktika, dan teknologi merupakan pengetahuan yang kompleks yang harus dimiliki oleh calon guru dan guru. Namun, hasil studi ini menunjukkan bahwa calon guru sekolah dasar masih memiliki pengetahuan matematika dan teknologi pada kategori cukup, dan khususnya pengetahuan didaktika mereka masih sangat rendah. Pengetahuan matematika, didaktika, dan teknologi yang kurang memadai ini tentu akan berdampak terhadap kemampuan mereka mengajar di sekolah nantinya. Oleh karena itu, institusi pendidikan wajib mengembangkan instruksional pembelajaran di perguruan tinggi yang 
mampu memperkuat pengetahuan mereka, terutama pengetahuan didaktika.

Terkait dengan penggunaan rasch model sebagai teknik analisis data, maka peneliti menemukan bahwa analisis ini mampu memberikan informasi terkait pengetahuan calon guru sekolah dasar dan juga tingkat kesulitan soal/ item yang diberikan (misalnya Gambar 4). Mengingat penelitian ini terbatas pada subjek dari sebuah institusi pendidikan, peneliti menyarankan untuk melakukan penelitian pengetahuan matematika, didaktika, dan teknologi calon guru dan juga guru pada subjek yang lebih banyak sehingga diperoleh hasil yang lebih akurat.

\section{UCAPAN TERIMA KasIH}

Peneliti mengucapkan terima kasih kepada LPPM UNRI dan KEMRISTEKDIKTI atas hibah penelitian dasar DRPM tahun 2021 no.1413/UN.19.5.1.3/PT.01.03/2021.

\section{Daftar Pustaka}

Cohan, L., Manion, L., \& Morrison, K. (2007). Research methods in education (Sixth Edit). Routledge.

Cueto, S., León, J., Sorto, M. A., \& Miranda, A. (2017). Teachers' pedagogical content knowledge and mathematics achievement of students in Peru. Educational Studies in Mathematics, 94(3), 329-345.

Depaepe, F., Torbeyns, J., Vermeersch, N., Janssens, D., Janssen, R., Kelchtermans, G., Verschaffel, L., \& Van Dooren, W. (2015). Teachers' content and pedagogical content knowledge on rational numbers: $A$ comparison of prospective elementary and lower secondary school teachers. Teaching and Teacher Education, 47, 82-92.

Fogarty, G., Cretchley, P., Harman, C., Ellerton, N., \& Konki, N. (2001). Validation of a questionnaire to measure mathematics confidence, computer confidence, and attitudes towards the use of technology for learning mathematics. Mathematics Education Research Journal, 13(2), 154-160.

Hu, H. W., Walker, K. M., \& Hsaio, W. Y. (2013). Developing elementary preservice teachers' technological, pedagogical, and content knowledge for learning and teaching division of fractions. International Journal of Technology, Knowledge and Society, 9(2), 185-204.

Kildan, A. O., \& Incikabi, L. (2015). Effects on the technological pedagogical content knowledge of early childhood teacher candidates using digital storytelling to teach mathematics. Education 3-13, 43(3), 238-248.

Liu, Q., Zhang, S., \& Wang, Q. (2015). Surveying Chinese in-service K12 teachers' technology, pedagogy, and content knowledge. Journal of Educational Computing Research, 53(1), 55-74.

Mailizar, M., Almanthari, A., Maulina, S., \& Bruce, S. (2020). Secondary School Mathematics Teachers ' Views on Elearning Implementation Barriers during the COVID-19 Pandemic: The Case of Indonesia. Eurasia Journal of Mathematics, Science and Technology Education, 16(7), 1-9.

Newton, K. J. (2008). An Extensive Analysis 
of Preservice Elementary Teachers' Knowledge of Fractions. American Educational Research Journal, 45(4), 1080-1110.

Pamuk, S., \& Peker, D. (2009). Turkish preservice science and mathematics teachers' computer related selfefficacies, attitudes, and the relationship between these variables. Computers and Education, 53(2), 454461.

Putra, Z. H. (2018). A praxeological analysis of pre-service elementary teachers' knowledge of rational numbers. Recherches En Didactique Des Mathematiques, 38(3), 315-364.

Putra, Z. H. (2019a). Danish pre-service teachers' mathematical and didactical knowledge of operations with rational numbers. International Electronic Journal of Mathematics Education, 15(1), 619-632.

Putra, Z. H. (2019b). Praxeological Change and the Density of Rational Numbers: The Case of Pre-service Teachers in Denmark and Indonesia. EURASIA Journal of Mathematics, Science and Technology Education, 15(5), 1-15.

Putra, Z. H., Witri, G., \& Sari, I. K. (2020). Pengetahuan Didaktika Calon Guru Sekolah Dasar tentang Pecahan Ditinjau dari Teori Antropologi Didaktik. Jurnal Elemen, 6(2), 244261.

Restiana, N., \& Pujiastuti, H. (2019). Pengukuran Technological Pedagogical Content Knowledge untuk Guru Matematika SMA di Daerah Tertinggal. Mosharafa: Jurnal Pendidikan Matematika, 8(1), 83-94.

Sumintono, B., \& Widhiarso, W. (2013). Aplikasi model rasch untuk penelitian ilmu-ilmu sosial. Trim Komunikasi Publishing House.

van Steenbrugge, H., Lesage, E., Valcke, M., Desoete, A., Steenbrugge, $H$. Van, Lesage, E., Valcke, M., \& Desoete, A. (2014). Preservice elementary school teachers' knowledge of fractions: A mirror of students' knowledge? Journal of Curriculum Studies, 46(1), 138-161.

\section{Riwayat Hidup PenUlis}

Zetra Hainul Putra, Ph.D.

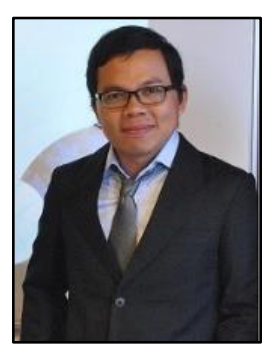

Lahir di Cimpago, 22 Juni 1985. Staf pengajar di Prodi PGSD, FKIP, UNRI. Studi S1 Matematika, UNRI, Pekanbaru, 2007; S2 Pendidikan Matematika UNSRI-Utrecht University, Palembang-Utrecht, 2011; dan S3 Didactics of Mathematics, Copenhagen, 2018.

\section{Dr. Neni Hermita, M.Pd.}

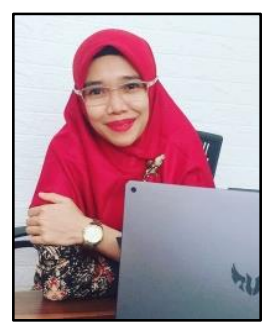

Lahir di Batu Rijal, 27 Februari 1984. Staf pengajar di Prodi PGSD, FKIP, UNRI. Studi S1 Pendidikan Fisika, UNRI, Pekanbaru, 2006; S2 Pendidikan Dasar, UPI, Bandung, 2008; dan S3 Pendidikan Dasar, UPI,

Bandung, 2017.

\section{Dr. Jesi Alexander Alim, M.Pd.}

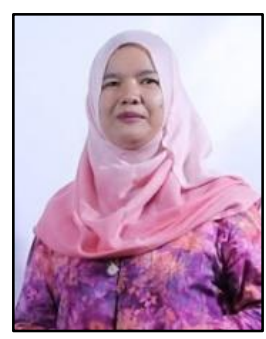

Lahir di Pekanbaru, 09 April 1980. Staf pengajar di Prodi PGSD, FKIP, UNRI. Studi S1 Pendidikan Matematika, UIR, Pekanbaru, 2005; S2 Pendidikan Dasar, UPI, Bandung, 2008; dan S3 Ilmu Pendidikan, UNP, Padang, 2020. 